\title{
Demand for Meat in Indonesia: Censored AIDS Model
}

Agus Widarjono, Sarastri Mumpuni Ruchba

Department of Economics, Faculty of Business and Economics, Universitas Islam Indonesia, Yogyakarta, Indonesia

\begin{abstract}
This study estimates the demand for meat in Indonesian urban households encompassing beef, goat, broiler chicken, and native chicken. We estimate the demand for meat using cross-sectional data from the 2013 Indonesian Socio-Economic Household Survey data, which records food expenditure for a week before the survey. Because of some zero expenditure, the Censored Almost Ideal Demand System (AIDS) using the consistent two-step estimation is applied. The estimated own-price elasticities indicate that all meat products are price-inelastic. Nonetheless, broiler chicken is the most responsive meat product while goat is the least responsive meat product to price changes. All meat products are normal good referring to the estimated income elasticities. However, Native chicken is the most responsive and goat is the most unresponsive to the income change. The estimated cross-price elasticities conclude that broiler chicken and beef are substitute goods. The policy simulation indicates that beef is a meat product that is unresponsive to price and income changes. Native chicken is the most responsive meat product to price and income change, followed by broiler chicken.
\end{abstract}

\section{Keywords}

Demand for meat, censored AIDS, price and income elasticity, urban Indonesia.

Widarjono, A. and Ruchba, S. M. (2021) "Demand for Meat in Indonesia: Censored AIDS Model", AGRIS on-line Papers in Economics and Informatics, Vol. 13, No. 2, pp. 109-119. ISSN 1804-1930. DOI 10.7160/aol.2021.130209.

\section{Introduction}

The world food crisis starting in 2004 has increased the food price index. Based on the FAO food price index, which consists of the average of five commodity group price indices (meat, dairy, cereals, vegetable oils, and sugar), the food price index increased from 161.4 in 2007 to 201.4 in 2008. It declined in 2009 and 2010, but it experienced a high spike to reach a peak of 229.9 in 2011. The food price index then declined again to 201.8 in 2014 and was 164 in 2015 . World meat prices also increased in line with rising world food prices. It was 130.8 in 2007 and then rose to 160.7 in 2008. It declined for the following two years, but then it jumped again in 2011 and reached the highest price in 2014 with the meat price index by 198.3 . However, the meat price index declined to 168.1 in 2015. Indonesia has also been experiencing a crisis of meat prices, especially the price of beef. The price of beef has been increasing steadily since 2013. The price of beef was approximately Indonesian Rupiah (IDR) 85,000 per $\mathrm{kg}$ in 2013. The price of beef has been above IDR 100,000 since 2014. Similarly, other meat products such as the price of broiler chicken have been increasing.
The price of broiler chicken also continued to increase since 2012. The price of broiler chicken was below IDR 20,000 per $\mathrm{kg}$ in 2011, but it has reached IDR 25,000 per $\mathrm{kg}$ in 2012 and was approximately IDR 27,000 per Kg in 2013 and in $2014^{1}$.

Chicken and beef are two meat products that are commonly consumed by households in Indonesia. Figure 1 presents chicken and beef consumption in Indonesia from 2007-2017. The average chicken consumption was $2.6 \mathrm{k}$ per capita per month from 2007-2017. Chicken consumption was relatively stable in the period 2007-2014 at $2 \mathrm{~kg}$ per capita per month. Chicken consumption has started to increase since 2015, with consumption levels above $3 \mathrm{~kg}$ per capita per month. Chicken consumption was close to $4 \mathrm{~kg}$ per capita per month in 2017. Consumption of beef was stable but it was relatively low. The average beef consumption was $0.21 \mathrm{~kg}$ per capita per month. Chicken consumption was higher than beef consumption because chicken is the main dish of meat products in the Indonesian household. Some factors affect

\footnotetext{
${ }^{1}$ The exchange rate of USD was approximately Indonesian Rupiah (IDR) 11,900 in 2014.
} 


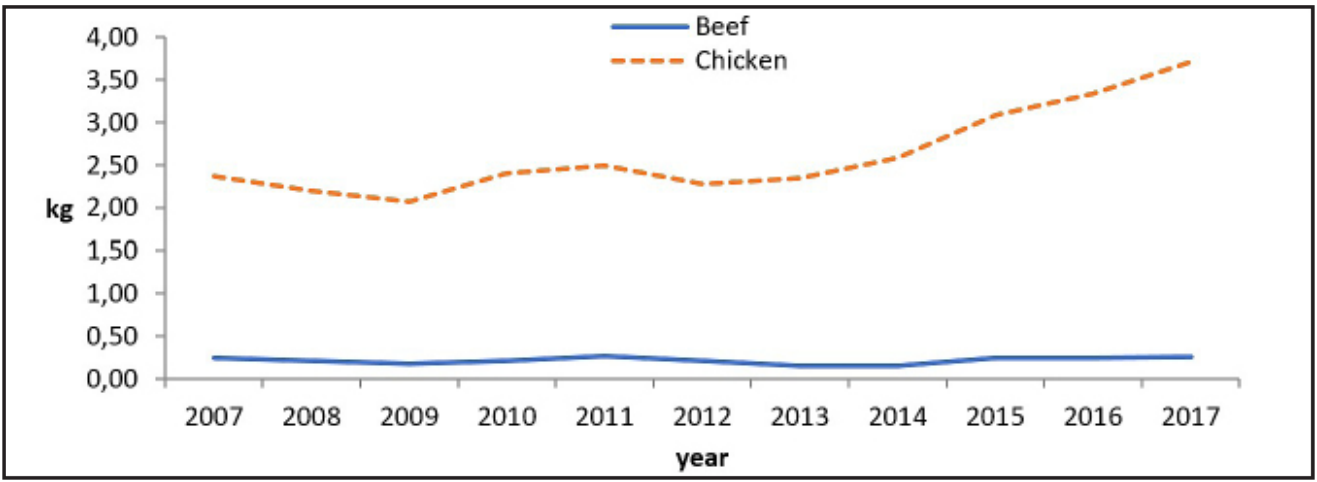

Source: own processing

Figure 1: Consumption of chicken and beef 2007-2017 (kg per capita per month).

low beef consumption in Indonesia. First, it is a lack of domestic production of beef. The capacity of domestic production for beef is only $70 \%$ and the rest of them are from import. Another factor is the location of cattle production and distant markets. The length of the production chain to consumers causes high transportation cost, which affects on the high price of beef. Overall, referring to Organization for Economic Co-operation and Development (OECD) data, meat consumption was relatively low in Indonesia with meat consumption by $11.5 \mathrm{~kg}$ per capita per year in 2017 , comparing to the Philippines $(31.6 \mathrm{~kg})$, Malaysia $(54.4 \mathrm{~kg})$, Thailand $(26.6 \mathrm{~kg})$, and Vietnam (55 $\mathrm{kg}$ ). Consequently, the average daily consumption of protein per capita was 56.7 grams and barely above minimum protein adequacy (52 grams) in 2016.

Many previous studies have investigated the demand for meat in Southeast Asian countries, which have similar consumer preferences. Hoang (2018) investigated food demand in Vietnam, including pork and other meats and seafood, using the 2010 Vietnam Household survey by applying the two-stage budgeting system (Working lesserQUAIDS). The estimated price elasticities of demand for pork (-0.844) and other meats and seafood (-0.834) are inelastic but expenditure elasticities of demand for pork (0.956) and other meats and seafood (1.199) are high. By employing the linear Almost Ideal Demand System (LA-AIDS), Lippe et al. (2010) estimated demand for meat as a part of demand food in urban households in Thailand using the 2007 household survey in Bangkok and Chiang Mai. The price elasticity and income elasticity for meat are -0.84 and 0.71 . By using Household expenditure survey 2004/2005, Sheng et al., (2008) employed the LA-AIDS model to estimate the complete demand system of food in Malaysia, including meat. They documented that both price and expenditure elasticities for meat are high by -1.1194 and 1.4064 , respectively. Sheng et al., (2010) applied the QUAIDS model to estimate the demand for meat in Malaysia consisting of beef, pork, mutton, and Poultry using Household expenditure survey $2004 / 2005$. The price elasticity for beef, pork, mutton, and poultry are -2.4776 , $-4.4401,-3.9767,-1.1057$, respectively while the expenditure elasticities for the associated meat products are $1.8971,1.1442,1.1520$, and 0.7002 , respectively.

Some previous empirical studies have examined the demand for meat in Indonesia such as Jensen and Manrique (1998), Hutasuhut et al. (2002), Widarjono and Rucbha (2016), Faharuddin et al. (2017), Faharuddin et al. (2019) among them. Jensen and Manrique (1998) investigated the demand for food based on income groups in urban areas using the Indonesian National SocioEconomic Survey (SUSENAS) in 1981, 1984, and 1987 by applying the LA-AIDS model. The price elasticity for meat varies from -0.81 to -0.91 , while the income elasticity ranges from 0.25 to 0.69 . By focusing two provinces consisting of provinces of DKI and West Java, which is about one-fourth of the population, Hutasuhut et al. (2002) using LA-AIDS model examined the demand for meat using household survey data from the 1990, 1993 and 1996 SUSENAS. The meat was grouped to four meat groups encompassing beef group, chicken groups, liver group, and untrimmed bones where the two last groups were not reported due to their relatively small shares in consumption. The beef group is price-inelastic (-0.919) and the chicken group is price-elastic (-1.088). Accordingly, the beef group is income-inelastic goods (0.634) and chicken group is income-elastic goods (1.141). 
Widarjono and Rucbha (2016) applying the two-stage budgeting (Working lesser- QUAIDS method) examined food demand in urban areas in Indonesia using data from the 2011 SUSENAS. Because of different consumer preferences across the country, the urban household was separated by Java Island as the main island and outside Java Island. Price elasticities for meat are from -0.552 to -1.001 and from -0.405 to -0.923 for the households in Java and outside Java Island, respectively. The income elasticities for meat are from 0.339 to 0.912 and from 0.353 to 0.624 for household in Java and outside Java. Faharuddin et al. (2017) applying the QUAIDS investigated the demand for food by household location (urban and rural area) using the 2013 SUSENAS. The price elasticities for meat are from -1.180 to -1.220 and expenditure elasticities for meat are from 1.445 to 1.564. Faharuddin et al., (2019) also investigated the demand for food from the 2013 first quarter SUSUNAS using the QUAIDS model. This study separated households into two groups consisting of agricultural households whose main income from agriculture and non-agricultural households. Based on price and income elasticity, meat demand for the agricultural household is more responsive $(-1.231$ and 1.600) than non-agricultural households $(-1.184$ and 1.454$)$ to price and income changes.

Previous studies such as Jensen and Manrique (1998), Widarjono and Rucbha (2016) (Faharuddin et al., 2017) and Faharuddin et al., (2019) have estimated the demand for aggregate meat as part of the analysis of food demand in Indonesia. Therefore, the analysis of the demand for meat as aggregate meat does not reflect the demand for various meat products such as beef, chicken, and mutton. To best our knowledge, only a few previous studies have focused on the demand for meat products in Indonesia such as Hutasuhut et al. (2002). This study estimates the demand for meat in Indonesia. The objectives of the study are twofold. First, it estimates the demand for meat for the urban household in Indonesia using the censored demand system approach. Second, this study also analyzes the impact of changes in meat prices and income on demand for meat for the urban household. This study is different from previous studies of demand for meat in Indonesia. First, this study focuses on the demand for meat consisting of beef, goat, broiler chicken, and native chicken. Second, unlike Hutasuhut et al., (2002) applying LA-AIDS, this study applies a non-linear AIDS model with censored AIDS to investigate the demand for meat. As shown by Alston et al. (1994), LA/AIDS using a linear price index leads to inaccurate price and expenditure elasticities.

\section{Materials and methods}

Our study uses cross-sectional data from the 2013 Indonesian National Socio-Economic Survey (SUSENAS) of households. SUSENAS is a household survey of all provinces in Indonesia and records food expenditure for a week before the survey. SUSENAS conducts household surveys for four rounds (quarterly basis) during a year. The first quarter or first round is January to March, the second quarter is April to June, the third quarter is July to September and the fourth quarter is October-December. Based on SUSENAS in 2013, the number of total households surveyed for all rounds was 284,064 households. Out of these total households, households living in urban areas were 121,322 households. Our study investigates the demand for meat in the urban households throughout Indonesia for all rounds. Because of the different behavior of meat consumption between rounds, we also include dummy variables of the quarter.

The SUSENAS does not report information on prices for each meat product. The price of each meat product is unit value instead of the market price. This price is calculating by dividing expenditure by quantity. Deaton (1990) discussed the limitation of unit value as price in estimating demand system. Estimating the demand system needs to have complete information about price. If missing or unreported prices existed, these prices are calculated by regressing the observed prices on regional dummies, seasonal dummies, and income (Heien and Pompelli, 1989; Jensen and Manrique, 1998). SUSENAS provides the income of household but there is a lot of missing income data. Therefore, total household expenditure is used as a proxy for income (Deaton, 1997).

Our study applies the demand system to estimate the demand for meat in Indonesia. The demand system model for meat demand is the Almost Ideal Demand System (AIDS) (Deaton and Muellbauer, 1980). The AIDS model is a widely used model for analyzing the demand for goods. By assuming weak separability, this study considers that meat is weakly separable from other food and nonfood in the budget of the consumer. With this given assumption, the AIDS model can be written as follows: 
$w_{i}=\alpha_{i}+\sum_{j=1}^{n} \gamma_{i j} \ln p_{j}+\beta_{i} \ln \left(\frac{x}{a(P)}\right)+u_{i}$

where subscripts $i$ and $j$ denotes meat products (beef, goat, broiler chicken and native chicken), $w_{i}$ is the budget share allocated for meat product $i, p_{j}$ is the price of the $\mathrm{j}^{\text {th }}$ meat product, $X$ is household expenditure on meat in the system, $a(P)$ is price index, $\gamma_{i j}$ and $\beta_{i}$ are parameter being estimated, $u_{i}$ is the error tem and $l n$ stands for natural logarithm.

There are two approaches to estimating the AIDS model with respect to the price index. The first approach is calculating the price index by using a linear price index such as the Stones price index known as Linear Approximation AIDS (LA-AIDS). Second, the price index is calculated by using the non-linear price index as in equation (2). The first approach results in inaccurate parameter estimation of AIDS models and then leads also bias elasticity of demand for both price and income elasticity (Alston et al., 1994). This study applies the second approach to results in an unbiased elasticity of meat demand. The price index is calculated as

$$
\begin{aligned}
\ln [a(P)] & =\alpha_{0}+\sum_{i=1}^{n} \alpha_{i} \ln p_{i}+ \\
& +0.5 \sum_{i=1}^{n} \sum_{j=1}^{n} \gamma_{i j} \ln p_{i} \ln p_{j}
\end{aligned}
$$

where $p_{i}$ and $p_{j}$ are price of meat product $i$ and $j$.

Demographic variables can also affect the consumption of goods. This demographic variable can be augmented in the intercept of equation (1). So the intercept for the AIDS model is as follows:

$$
\alpha_{i}=\rho_{i 0}+\sum_{k=1}^{m} \rho_{i k} d_{k}
$$

Where $d_{k}$ is the demographic variable consisting of household size (number of persons in a household) and dummy variable (quarters 2, 3 , and 4). Due to differences in the timing of meat consumption in SUSENAS data, the study included a dummy variable to distinguish between quarters. The three dummy variables are the second, third, and fourth quarter while the first quarter is the basis of comparison. The characteristics of demand theory can be applied to equation (1) by restricting the parameters (Deaton and Muellbauer, 1980). The restrictions are addingup $\sum_{i=1}^{n} \rho_{i 0}=1 ; \quad \sum_{i=1}^{n} \rho_{i k}=0 ; \quad \sum_{i=1}^{n} \gamma_{i j}=0$;

$\sum_{i=1}^{n} \beta_{i}=0 ; \quad$ and $\quad \sum_{i=1}^{n} \lambda_{i}=0 ;$ homogeneity $\sum_{=1}^{n} \gamma_{i j}=0$ for each $i$; and Slutsky symmetry $\gamma_{i j}=\gamma_{j i}, \quad i \neq j$.
SUSENAS records all food expenditure as well as non-food expenditure. However, some households did not buy some meat products during the survey. Therefore, their expenditures on meat products were zero expenditure. Survey data from the 2013 SUSENAS show the percentage of urban households, who did not buy beef, goat, broiler chicken, and native chicken, were 93.58\%; $99.8 \% ; 60.1 \%$ and $96.82 \%$ at the time of the survey respectively. Zero expenditure in the dependent variable means that the dependent variables are the limited dependent variables or the censored model in the demand system.

The limited dependent variable in the demand system leads to biased estimation. To overcome this biased estimation, the demand system equation involves a two-steps estimation (Heckman, 1978). First, a probit regression is computed that determines the probability that a given household will consume the good in question. The probit regression is used to calculate the probability of each household. Second, we include the probability to estimate the demand system. Heien et al. (1990) apply the inverse Mills ratio as an instrument that incorporates the censoring latent variables in the second stage estimation of the demand system using seemingly unrelated regression (SUR). However, Shonkwiler and Yen (1999) prove that this method leads to an inconsistent estimator and propose the twostep estimation procedure for a system of equations with limited dependent variables.

This study applies consistent two-step estimation procedures to estimate the demand for meat in Indonesia (Shonkwiler and Yen, 1999; Yen et al., 2002). The first step is to estimate the probability of buying a given meat product using probit regression (Yen et al., 2002; Pan et al., 2008). The probit regression for meat demand can be written as follow:

$$
\begin{aligned}
& \operatorname{prob}\left(y_{i t}=1 \mid Z_{h}\right)=\theta\left(Z_{\boldsymbol{h}}^{\prime} \boldsymbol{\tau}_{\boldsymbol{i}}\right) \\
& \operatorname{prob}\left(y_{i t}=0 \mid Z_{h}\right)=1-\theta\left(\boldsymbol{Z}_{\boldsymbol{h}}^{\prime} \boldsymbol{\tau}_{\boldsymbol{i}}\right)
\end{aligned}
$$

where $\theta$ is the probit function model, $Z_{h}$ is the vector of explanatory variables and $\tau_{i}$ is the vector of estimated parameters,

The explanatory variables in the first step include the logarithms of the prices of four types of meats, the logarithm of total household expenditure both for food and non-food items, and the demographic variables previously defined in equation (3). The probit regression results in the estimated probability density function (PDF) and cumulative 
distribution function (CDF). The next step includes the PDF as well as the CDF in AIDS. Therefore, the censored AIDS model used in this study follows (Shonkwiler and Yen, 1999):

$$
\begin{aligned}
w_{i} & =\left\{\alpha_{i}+\sum_{j=1}^{n} \gamma_{i j} \ln p_{j}+\beta_{i} \ln \left(\frac{x}{a(P)}\right)+\right. \\
& \left.+u_{i}\right\} \Phi(.)+\tau_{i} \varphi(.)+\varepsilon_{i}
\end{aligned}
$$

where $\Phi$ is the cumulative distribution function and $\varphi$ is the probability distribution function.

The AIDS model in equation (6), therefore, is a censor demand system model. In the censored AIDS model, the adding-up condition does not hold in the demand system of equation (6). Therefore, following Yen et al. (2002), we should estimate an entire system equation in equation (6) in the second step by putting a restriction on homogeneity and symmetry conditions. This consistent two-step (CTS) estimation is estimated using the maximum information likelihood (FIML) (Zheng and Henneberry, 2010; Widarjono and Rucbha, 2016).

The price elasticity for each meat product based on the censored AIDS model is calculated as follows:

$$
e_{i j}=\frac{1}{W_{i}}\left\{\gamma_{i j}-\beta_{i}\left(\alpha_{i h}+\sum_{j=1}^{n} \gamma_{i j} \ln p_{j}\right)\right\} \Phi_{i}-\delta_{i j}
$$

where $\delta_{i j}$ is the Kronecker delta, which is 1 as $i \neq j$, otherwise $\delta_{i j}=1$. The expenditure elasticity for each meat product is calculated as:

$$
e_{i}=1+\frac{1}{W_{i}}\left[\beta_{i}\right] \Phi_{i}
$$

The price and expenditure elasticities are calculated on the basis of the estimated parameter and sample means of variables. For statistical inferences, the standard errors for price and expenditure elasticities are estimated using the delta method. Our study applies SAS software in all estimations.

The next step is to use the demand elasticity for meat both price and income elasticity to investigate the effects of price and income changes on the consumption of meat products. Through the interdependent demand relationship among meat products, the particular meat consumed is influenced by changes in a particular meat's price and/- or the per capita meat expenditure (Huang, 1996; Zheng and Henneberry, 2012; Zheng et al., 2019). The change in meat product per capita is a function of the price of meat product and income change as follows:

$$
\Delta \ln \theta_{k}=\sum_{j} \pi_{k j} \Delta \ln p_{j}+\eta_{k} \Delta \ln y
$$

where $\Delta \ln \theta_{k}=\Delta \theta_{k} / \theta_{k}$ is a percentage change in consumption of meat product per capita, $\Delta \ln p_{j}=\Delta p_{j} / p_{j} \quad$ is a percentage change in the price of meat product, $\Delta \ln y=\Delta y / y$ is a percentage change in income of households, $\pi_{k j}$ is the estimated price elasticity, and $\eta_{k}$ is the estimated expenditure elasticity.

\section{Results and discussion}

Table 1 describes the consumption of meat products consisting of beef, goat, broiler chicken, and native chicken from the 2013 SUSENAS. Consumption of broiler chicken is the largest consumption of urban households in Indonesia, with an average of $0.7865 \mathrm{~kg}$ per capita per week followed by beef $(0.0759 \mathrm{~kg})$, native chicken $(0.0729 \mathrm{~kg})$, and goat $(0.0031 \mathrm{~kg})$. As the meat product consumed by most Indonesian urban households, expenditure for broiler chicken has the largest portion in the urban household in Indonesia by $83.46 \%$ of total household expenditure for meat consumption followed by beef, native chicken, and goat.

Before estimating the AIDS model, the first step is to estimate the probit model. Estimation results of the probit model for the demand for beef, goat, broiler chicken, and native chicken are shown in Table 2. The Household size has a negative impact and statistically significant at $\alpha=1 \%$ on all probit models for each meat product. This means that household size affects the probability of buying meat. Of all dummy variables, ten dummy variables $(83.3 \%)$ are statistically significant at $\alpha=1 \%$. These results indicate that temporal (quarter) effects are important in explaining meat consumption patterns in Indonesian urban households. Probit estimation shows that the price of each meat product and household expenditure is the dominant factor for buying meat products. Out of the 16 price variables, there are 12 price variables (75\%) affecting the probability of buying meat products. Meanwhile, all expenditure variables have a positive impact and statistically significant in affecting the probability of buying meat products.

Having PDF and CDF from the probit model, the next step is to estimate the AIDS model by augmenting PDF and CDF into the AIDS model. Table 3 presents the results of AIDS parameter estimation with the non-linear price index where the independent variable is the budget share for each meat product. Three independent variables are demographic variables consisting of quarterly dummy variables and the number of families, economic variables comprising price and expenditure and probability 


\begin{tabular}{lcccc}
\hline & Mean & Std Dev & Minimum & Maximum \\
\hline & \multicolumn{2}{c}{ Consumption of meat } & products & $(\mathrm{kg}$ /household/week) \\
Beef $(\mathrm{kg})$ & 0.0759 & 0.2386 & 0 & 7.4 \\
Goat $(\mathrm{kg})$ & 0.0031 & 0.0566 & 0 & 2.5 \\
Broiler chicken $(\mathrm{kg})$ & 0.7865 & 0.6199 & 0 & 14 \\
Native chicken $(\mathrm{kg})$ & 0.0729 & 0.3300 & 0 & 9.6 \\
& & Meat product expenditure share & \\
Budget share of beef & 0.1016 & 0.2620 & 0 & 1 \\
Budget share of goat & 0.0032 & 0.0521 & 0 & 1 \\
Budget share of broiler chicken & 0.8346 & 0.3389 & 0 & 1 \\
Budget share of native chicken & 0.0605 & 0.2279 & 0 & 1 \\
& & & & \\
\hline
\end{tabular}

Source: The 2013 SUSENAS. The number of urban households is 121,322.

Table 1: Summary Statistics, Demand for Meat Products, Urban Households, Indonesia, 2013.

\begin{tabular}{lllll}
\hline \multirow{2}{*}{ Variable } & \multicolumn{4}{c}{ Meat products } \\
\cline { 2 - 5 } & \multicolumn{1}{c}{ Beef } & \multicolumn{1}{c}{ Goat } & Broiler chicken & Native chicken \\
\hline Intercept & $15.9421^{* * *}$ & $8.5636^{* *}$ & $21.1080^{* * *}$ & $10.3163^{* * *}$ \\
Household size & $(1.3337)$ & $(3.7920)$ & $(1.1052)$ & $(1.7646)$ \\
& $-0.1344^{* * *}$ & $-0.0389^{* * *}$ & $-0.0269^{* * *}$ & $-0.0200^{* * *}$ \\
Dummy variable of quarter 2 & $(0.0036)$ & $(0.0121)$ & $(0.0021)$ & $(0.0041)$ \\
& $0.0968^{* * *}$ & -0.0309 & $0.0487^{* * *}$ & $0.1056^{* * *}$ \\
Dummy variable of quarter 3 & $(0.0187)$ & $(0.0627)$ & $(0.0116)$ & $(0.0213)$ \\
& $-0.1198^{* * *}$ & $-0.2259^{* * *}$ & $-0.2273^{* * *}$ & -0.0039 \\
Dummy variable of quarter 4 & $(0.0274)$ & $(0.0662)$ & $(0.0200)$ & $(0.0330)$ \\
& $-0.2398^{* * *}$ & $-0.1883^{* * *}$ & $-0.3126^{* * *}$ & $-0.1100^{* * *}$ \\
Log of beef price & $(0.0250)$ & $(0.0677)$ & $(0.0181)$ & $(0.0316)$ \\
Log of goat price & $-1.5598^{* * *}$ & -0.0602 & $-0.1011^{* *}$ & $-0.3305^{* * *}$ \\
& $(0.0539)$ & $(0.2313)$ & $(0.0499)$ & $(0.0732)$ \\
Log of broiler chicken price & $-1.1010^{* * *}$ & $-1.5781^{* * *}$ & $-1.6542^{* * *}$ & -0.2007 \\
& $(0.1329)$ & $(0.1574)$ & $(0.1054)$ & $(0.1693)$ \\
Log of native chicken price & -0.0348 & 0.0474 & $-1.2660^{* * *}$ & $0.1253^{* * *}$ \\
& $(0.0386)$ & $(0.1378)$ & $(0.0248)$ & $(0.0487)$ \\
Log of expenditure & $-0.2082^{* * *}$ & 0.0555 & $-0.0914^{*}$ & $-1.4538^{* * *}$ \\
& $(0.0815)$ & $(0.2849)$ & $(0.0579)$ & $(0.0510)$ \\
& $1.0180^{* * *}$ & $0.3765^{* * *}$ & $0.8037^{* * *}$ & $0.5220^{* * *}$ \\
\hline
\end{tabular}

Note: ***;*; * are statistically significant at the $1 \% ; 5 \% ; 10 \%$, respectively. The numbers in parentheses are standard error.

Source: Author's calculation

Table 2: Probit Estimation, Urban Households, Indonesia, 2013.

variables encompassing the CDF and PDF. There are 16 demographic variables estimated in the meat demand system. Out of the 16 variables, 14 variables $(87.5 \%)$ are statistically significant at $\alpha=10 \%$ or lower. This means that most demographic variables affect the demand for meat in Indonesia, especially household size. Moreover, dummy variables, which show temporal effects, are also the key factor in determining meat consumption patterns in Indonesian urban households.

All 20 economic variables consisting of 16 prices of all meat products and four expenditure variables are statistically significant at $\alpha=1 \%$. The PDF variables are also statistically significant at $\alpha=1 \%$. The significance of all these PDF variables suggests 
that there is a high probability that households who did not buy meat during the survey will buy meat at the outside survey as the SUSUNAS records household expenditure only for a week before the survey. This study, therefore, should include households who did not buy meat products during the survey in estimating the demand for meat in the AIDS demand system. Therefore, our estimation leads to bias results as we fail to include for those who are with zero expenditure in their consumer budget during the household survey.

The estimated parameter of AIDS in Table 3 is then used to calculate the elasticity of demand both price and expenditure. The price and expenditure elasticities are calculated using equations (7) and (8). The own-price elasticity is shown by the diagonal of the matrix while the cross-price elasticity is indicated by the off-diagonal matrix in Table 4 for each meat product encompassing beef, goat, broiler chicken, and native chicken. All own-price and cross-elasticities are statistically significant at $\alpha=1 \%$. All Expenditure elasticities, which are presented at the bottom of Table 4, are statistically significant at $\alpha=1 \%$.

All own-price elasticities are a negative sign. These results are consistent with the demand theory, which explains the negative relationship between the demand for goods and its price. The own-price elasticity for beef, goat, broiler chicken, and native chicken are - 0.9608; -0.7523; - 0.9864; -0.9811 respectively. Based on the own-price elasticity, the results indicate that if the prices of meat products rise (fall) then demand for that meat products decrease (increase). For instance, the 1\% increase in beef price results in by roughly $0.9608 \%$ decrease in beef demand, holding other factors constant. The results show that each meat product is inelastic. The results may conclude that a variety of substitute meat product is not available for consumers. These findings are line with the previous study

\begin{tabular}{|c|c|c|c|c|}
\hline \multirow[b]{2}{*}{ Variable } & \multicolumn{4}{|c|}{ Meat products } \\
\hline & Beef & Goat & Broiler chicken & Native chicken \\
\hline \multirow[t]{2}{*}{ Intercept } & $0.6219 * * *$ & $-1.3999 * * *$ & $0.3927 * * *$ & $0.3477 * * *$ \\
\hline & $(0.0032)$ & $(0.0190)$ & $(0.0032)$ & $(0.0068)$ \\
\hline \multirow[t]{2}{*}{ Household size } & $-0.0059 * * *$ & $0.1433 * * *$ & $0.0235 * * *$ & $-0.0235 * * *$ \\
\hline & $(0.0002)$ & $(0.0036)$ & $(0.0001)$ & $(0.0006)$ \\
\hline \multirow[t]{2}{*}{ Dummy variable of quarter 2} & $-0.0160 * * *$ & $0.5291 * * *$ & $-0.0115 * * *$ & 0.0032 \\
\hline & $(0.0011)$ & $(0.0463)$ & $(0.0007)$ & $(0.0026)$ \\
\hline \multirow[t]{2}{*}{ Dummy variable of quarter 3} & $-0.0261 * * *$ & $0.7057 * * *$ & $-0.0092 * * *$ & $-0.0848 * * *$ \\
\hline & $(0.0011)$ & $(0.0265)$ & $(0.0007)$ & $(0.0033)$ \\
\hline \multirow[t]{2}{*}{ Dummy variable of quarter 4} & -0.0006 & $0.8511 * * *$ & $-0.0078 * * *$ & $-0.1039 * * *$ \\
\hline & $(0.0012)$ & $(0.0215)$ & $(0.0007)$ & $(0.0044)$ \\
\hline \multirow[t]{2}{*}{ Log of beef price } & $-0.1146 * * *$ & $-0.3343 * * *$ & $0.2245 * * *$ & $-0.0715 * * *$ \\
\hline & $(0.0015)$ & $(0.0026)$ & $(0.0013)$ & $(0.0040)$ \\
\hline \multirow[t]{2}{*}{ Log of goat price } & $-0.3343 * * *$ & $0.5109 * * *$ & $-0.0670 * * *$ & $-0.1096 * * *$ \\
\hline & $(0.0026)$ & $(0.0070)$ & $(0.0021)$ & $(0.0075)$ \\
\hline \multirow[t]{2}{*}{ Log of broiler chicken price } & $0.2245^{* * *}$ & $-0.0670 * * *$ & $-0.3034 * * *$ & $0.1460 * * *$ \\
\hline & $(0.0013)$ & $(0.0021)$ & $(0.0019)$ & $(0.0028)$ \\
\hline \multirow[t]{2}{*}{ Log of native chicken price } & $0.2245 * * *$ & $-0.1096 * * *$ & $0.1460 * * *$ & $0.0351 * * *$ \\
\hline & $(0.0013)$ & $(0.0075)$ & $(0.0028)$ & $(0.0048)$ \\
\hline \multirow[t]{2}{*}{ Log of Expenditure } & $-0.5168 * * *$ & $-0.6770 * * *$ & $-0.4812 * * *$ & $0.0806 * * *$ \\
\hline & $(0.0022)$ & $(0.0217)$ & $(0.0023)$ & $(0.0037)$ \\
\hline \multirow[t]{2}{*}{$\mathrm{CDF}$} & $0.5664 * * *$ & $-0.4874 * * *$ & $0.4852 * * *$ & $-0.0788 * * *$ \\
\hline & $(0.0044)$ & $(0.0385)$ & $(0.0028)$ & $(0.0106)$ \\
\hline \multirow[t]{2}{*}{ PDF } & $2.7107 * * *$ & $2.8638 * * *$ & $5.0890 * * *$ & $0.5418 * * *$ \\
\hline & $(0.0128)$ & $(0.0425)$ & $(0.0108)$ & $(0.0164)$ \\
\hline
\end{tabular}

Note: $* * * ; * ; *$ are statistically significant at the $1 \% ; 5 \% ; 10 \%$, respectively. The numbers in parentheses are standard error.

Source: Author's calculation

Table 3: Estimated Parameters of AIDS, Urban Households, Indonesia, 2013. 


\begin{tabular}{|c|c|c|c|c|}
\hline \multirow{2}{*}{ Variable } & \multicolumn{4}{|c|}{ Meat products } \\
\hline & Beef & Goat & Broiler chicken & Native chicken \\
\hline & \multicolumn{4}{|c|}{ Consumption of meat products ( $\mathrm{kg} /$ household/week) } \\
\hline \multirow[t]{2}{*}{ Price of beef } & $-0.9608 * * *$ & $-0.4353 * * *$ & $0.5073 * * *$ & $0.5073 * * *$ \\
\hline & $(0.0022)$ & $(0.0068)$ & $(0.0019)$ & $(0.0019)$ \\
\hline \multirow[t]{2}{*}{ Price of goat } & $-0.1035 * * *$ & $-0.7523 * * *$ & $0.3236^{* * *}$ & $-0.0631 * * *$ \\
\hline & $(0.0057)$ & $(0.0101)$ & $(0.0117)$ & $(0.0051)$ \\
\hline \multirow[t]{2}{*}{ Price of broiler chicken } & $0.2115^{* * *}$ & $-0.1226^{* * *}$ & $-0.9864 * * *$ & $0.0961^{* * *}$ \\
\hline & $(0.0009)$ & $(0.0037)$ & $(0.0023)$ & $(0.0029)$ \\
\hline \multirow[t]{3}{*}{ Price of native chicken } & $-0.0583 * * *$ & $-0.0512 * * *$ & $0.0551^{* * *}$ & $-0.9811 * * *$ \\
\hline & $(0.0028)$ & $(0.0048)$ & $(0.0029)$ & $(0.0028)$ \\
\hline & \multicolumn{4}{|c|}{ Meat product expenditure share } \\
\hline \multirow[t]{2}{*}{ Expenditure } & $0.5449^{* * *}$ & $0.4434 * * *$ & $0.7268^{* * *}$ & $1.0487^{* * *}$ \\
\hline & $(0.0019)$ & $(0.0179)$ & $(0.0013)$ & $(0.0023)$ \\
\hline
\end{tabular}

Note: $* * * * * ; *$ are statistically significant at the $1 \% ; 5 \% ; 10 \%$, respectively. The numbers in parentheses are standard error.

Source: Author's calculation.

Table 4: Price and Expenditure Elasticity, Urban Households, Indonesia, 2013.

by Hutasuhut et al., (2002) using LA-AIDS who documented that beef is price inelastic but chicken is price elastic. However, estimating demand elasticity using a linear price in LA-AIDS leads to overestimate results (Alston et al.,1994). The price elasticities for meat products in this study are quite different from the empirical study of demand for meat products in Malaysia for which price elasticity is elastic due to the availability of various substitute meat products in Malaysia (Sheng et al., 2010).

The cross-price elasticity for each meat product results in different conclusions. On beef demand, the goat is complementary goods to beef because its cross-price elasticity is negative while broiler chicken and native chicken are substitute goods to beef. In the case of broiler chicken, the goat is a complementary good to broiler chicken while beef and native chicken are substitution goods to broiler chicken. On demand for goat, broiler chicken is a substitute to the goat while beef and native chicken are complementary goods to the goat. On demand for native chicken, broiler chicken is substitute goods and beef and goat are complementary goods. Generally, it can be concluded that broiler chicken and beef are substitute goods. These results are in accordance with the pattern of meat consumption in Indonesian urban households where broiler chicken is the main menu of meat products followed by beef. These results support the previous empirical study conducted by Hutasuhut et al., (2002) that indicated that broiler chicken and beef are substitute goods in urban households in Jakarta as a capital city of Indonesia and west java province which borders Jakarta.
At the bottom part of table 4 shows the expenditure elasticity. All expenditure elasticities are positive as expected for basic food as normal goods. The expenditure elasticities for beef, goat, broiler chicken, and native chicken are 0.5449; 0.4434; 0.7268 ; and 1.0487 , respectively. The results may conclude that as income increases by \%, demand for broiler chicken is expected to increase approximately by $0.7268 \%$. The elasticity of expenditure indicates that beef, goat, and broiler chicken are income-inelastic goods while the native chicken is income-elastic goods because native chicken is a chicken product that is more delicious and healthier than broiler chicken (Ali et al., 2019). These results are in line with previous empirical study. Hutasuhut et al. (2002) using different SUSENAS data during 1990's revealed that demand for beef is income-inelastic but chicken demand is income-elastic. Nevertheless, Indonesia's income per capita has increased remarkably recently from US\$ 1,026 per capita in 1995 to US\$ 3,624 in 2013. According to Engle's law, moving from low-income country to middle-income country has changed considerably income elasticity for meat products which is expected to be inelastic, smaller than those of $1990 \mathrm{~s}$. Yet, the income elasticities for meat products are much smaller than those of the demand for meat products in Malaysia for which meat products are income-elastic (Sheng et al., 2010).

Next, having estimated demand elasticity consisting of price and expenditure elasticities, both elasticities are then used to perform policy simulations. This policy simulation is to analyze the impact of changes in the price of meat products 


\begin{tabular}{lccccccc}
\hline & $\begin{array}{c}\text { Average } \\
\text { Consumption } \\
\text { Meat products }\end{array}$ & \multicolumn{2}{c}{ Scenario 1 } & \multicolumn{2}{c}{ Scenario 2 } & \multicolumn{2}{c}{ Scenario 3 } \\
\cline { 3 - 8 } & $(\mathrm{kg})$ & Quantity & $\%$ & Quantity & $\%$ & Quantity & $\%$ \\
\hline Beef & 0.0760 & -0.00345 & 4.54 & -0.0029 & 3.82 & -0.0070 & 9.26 \\
Goat & 0.0031 & -0.00005 & 1.67 & -0.0002 & 5.95 & -0.0003 & 10.39 \\
Broiler chicken & 0.7865 & -0.06094 & 7.75 & -0.0630 & 8.01 & -0.1202 & 15.28 \\
Native chicken & 0.0729 & -0.00002 & 0.03 & -0.0075 & 10.35 & -0.0152 & 20.84 \\
\hline
\end{tabular}

Note: Scenario 1 refers to the prices of broiler chicken and beef rises by $10 \%$. Scenario 2 refers to all prices rises by $10 \%$. Scenario 3 refers to all prices rises and income fall by $10 \%$.

Source: Author's calculation

Table 5: Effect of Change in Price and Income on demand for meat product,

Urban Household, Indonesia, 2013

and expenditure on the consumption of meat products in Indonesian urban households. Huang (1996) states that change in per capita meat product consumption is a function of changes in the price of meat product and income. From this simulation can be investigated how the change of meat product consumption is as the price of meat product and expenditure of household change.

In this study, policy simulations are conducted with several scenarios to analyze the impact of price's meat products and expenditure changes on the consumption of meat products. The first scenario is the increase in prices of broiler chicken and beef by $10 \%$ to meat product consumption holding that household's income does not change. This scenario is based on the budget share in the 2013 SUSENAS where broiler chicken and beef are the main menus of meat consumption for households in urban Indonesia. The second scenario is an increase in all the prices of meat products by $10 \%$ to the consumption of meat products holding that household's income is unchanged. The third scenario is an increase in all prices of meat products by $10 \%$ and a reduction in household income by $10 \%$ to meat products consumption.

The results of the policy simulation are shown in Table 5. In the first scenario, it decreases all consumption of meat products. Consumption of broiler chicken, beef, goat, and native chicken decreases by $0.061094 \mathrm{~kg} ; 0.00345 \mathrm{~kg} ; 0.00005$ $\mathrm{kg}$; and $0.00002 \mathrm{~kg}$ per week, respectively. The first scenario causes a reduction in broiler chicken consumption by $7.75 \%$, followed by beef (4.54\%). Scenario 2 decreases the consumption of native chicken by $10.35 \%$, followed by broiler chicken $(8.01 \%)$, goat $(5.95 \%)$, and beef $(3.85 \%)$. The third scenario leads to a decline in the consumption of all types of meat with the highest decrease in native chicken, followed by broiler chicken, goat, and beef. A remarkable reduction in the consumption of native chicken indicates that native chicken is not the main menu of meat product consumption in Indonesian urban households. Beef is a meat product whose level of consumption is unresponsive to price and income changes.

\section{Conclusion}

This study estimated the demand for meat for Indonesian Urban Household using the demand system. The complete demand system was estimated using the non-linear Almost Ideal Demand System. The 2013 National Social and Economic Survey of Household in Indonesia was used to accomplish this study. This study finds some important results. First, all estimated own-price elasticities are negative and inelastic as expected. Broiler chicken is the most responsive to price changes and goat is the least responsive to price changes. The next finding shows that broiler chicken and beef are substitute goods based on the estimated cross-price elasticity. Broiler chicken is the main menu of meat followed by beef. These findings are consistent with the consumption pattern of meat products for urban households in Indonesia. Third, all estimated expenditure elasticities are positive. However, native chicken is the most responsive meat products and goat is the most unresponsive meat product to the income change. Fourth, based on policy simulation, beef is a meat product whose level of consumption is less responsive to price and income changes. On the other hand, native chicken is most responsive to price and income change.

The important implication can be inferred from this study. Broiler chicken as the main dish of meat products in urban households is very responsive to price change, implying an increase in price of broiler lowers meat consumption from this particular meat. Nonetheless, beef as a substitute meat product for broiler chicken 
is very expensive. With limited available substitute meat products, consumption of meat products reduces considerably as the price of broiler chicken rises and then lowers protein intake which leads to protein deficiency. So, the government should stabilize the price of broiler chicken through ceiling price policy during the price crisis of meat products such as in 2013 in order to maintain the adequacy consumption of meat products.

There are some limitations to this study. First, by assuming the linear Engle curve, the AIDS model leads to inaccurate estimation because basic food such as meat products may not be linear related to income as to nonlinearity of the Engel curve. Second, this study examines only urban households. However, consumption patterns of meat product consumption are geographically different in Indonesia. Lastly, because of ongoing rapid urbanization in Indonesia, these results may not reflect the consumption of meat products in recent conditions.

Corresponding authors

Agus Widarjono Ph.D

Department of economics, Faculty of Business and Economics

Universitas Islam Indonesia, Yogyakarta, Indonesia

Condong Catur Depok Sleman, Yogyakarta, Indonesia 55283

Phone: 062274 881546,E-mail: agus.widarjono@uii.ac.id

\section{References}

[1] Ali, M., Lee S., Park, J., Jung, S., Jo, C. and Nam, K (2019) "Comparison of Functional Compounds and Micronutrients of Chicken Breast Meat by Breeds", Food Science of Animal Resources, Vol. 39, No. 4, pp. 632-642. E-ISSN 2636-0780, ISSN 2636-0772. DOI 10.5851/kosfa.2019.e54.

[2] Alston, J. M., Foster, K. A. and Green, R. D. (1994) "Estimating Elasticities with the Linear Approximate Almost Ideal Demand System: Some Monte Carlo Results", The Review of Economics and Statistics, Vol. 76, No. 2, pp. 351-356. E-ISSN 1530-9142, ISSN 0034-6535. DOI 10.2307/2109891.

[3] Deaton, A. (1990) "Price Elasticities from Survey Data: Extensions and Indonesian Results", Journal of Econometrics, Vol. 44, pp. 281-309. ISSN 0304-4076. DOI 10.1016/0304-4076(90)90060-7.

[4] Deaton, A. (1997) "The Analysis of Household Survey: A Microeconometric Approach to Development policy", Baltimore: John Hopkin University Press.

[5] Deaton, A. and Muellbauer, J. (1980) "An Almost Ideal Demand System", The American Economic Review, Vol. 70, No. 3, pp. 312-326. E-ISSN 1944-7981, ISSN 0002-8282.

[6] Faharuddin, F., Yunita, Y., Mulyana, A., Yamin, M. and Habito, C. F. (2019) "'Agricultural Households' Food Demand: Evidence from Indonesia", Asian Journal of Agriculture and Development, Vol. 16, No. 2, pp. 45-60. ISSN 1656-4383. DOI 10.22004/ag.econ.298424.

[7] Faharuddin, F., Yunita, Y., Mulyana, A., and Yamin, M. (2017) "Nutrient elasticities of food consumption: the case of Indonesia", Journal of Agribusiness in Developing and Emerging Economies, Vol. 7, No. 3, pp. 198-217. ISSN 2044-0839. DOI 10.1108/JADEE-02-2016-0008.

[8] Heckman, J. J. (1978) "Dummy Endogenous Variables in a Simultaneous Equation System", Econometrica, Vol. 46, No. 4, pp. 931-959. E-ISSN 1468-0262, ISSN 0012-9682. DOI $10.2307 / 1909757$.

[9] Heien, D. and Wessells, C. R (1990) "Demand Systems Estimation With Microdata: A Censored Regression Approach", Journal of Business and Economic Statistics, Vol. 8, No. 3, pp. 365-371. ISSN 07350015. DOI 10.2307/1391973.

[10] Heien, D. and Pompelli, G. (1989) "The Demand for Alcoholic Beverages: Economic and Demographic Effects", Southern Economic Journal, Vol. 55, No. 3, pp. 759-770. E-ISSN 2325-8012. DOI 10.2307/1059587.

[11] Hoang, H. K. (2018) "Analysis of food demand in Vietnam and short-term impacts of market shocks on quantity and calorie consumption", Agricultural Economics, Vol. 49, No. 1, pp. 83-95. E-ISSN 1574-0862. DOI 10.1111/agec.12397. 
[12] Huang, K. S. (1996) "Nutrient Elasticities in a Complete Food Demand System", American Journal of Agricultural Economics, Vol. 78, No. 1, pp. 21-29. E-ISSN 1467-8276. DOI 10.2307/1243775.

[13] Hutasuhut, M., Chang, H., Griffith, G., O'Donnell, C. and Doran, H. (2002) "The Demand for Beef in Indonesia: Implications for Australian Agribusiness", Australian Agribusiness Review, Vol. 10, pp. 1-10. ISSN 1442-6951.

[14] Jensen, H. H. and Manrique, J. (1998) "Demand for food commodities by income groups in Indonesia", Applied Economics, Vol. 30, No. 4, pp. 491-501. E-ISSN 1466-4283, ISSN 0003-6846. DOI 10.1080/000368498325750.

[15] Lippe, R. S., Isvilanonda, S., Seebens, H. and Qaim, M. (2010) "Food Demand Elasticities among Urban Households in Thailand", Thammasat Economic Journal, Vol. 28, No. 2, pp. 1-29. [Online]. Available: https://so05.tci-thaijo.org/index.php/TER/article/view/137355 [Accessed: 10 Oct. 2019].

[16] Pan, S., Mohanty, S. and Welch, M. (2008) "India Edible Oil Consumption: A Censored Incomplete Demand Approach", Journal of Agricultural and Applied Economics, Vol. 40, No. 3, pp. 821-835. E-ISSN 2056-7405, ISSN 1074-0708. DOI 10.1017/s1074070800002352.

[17] Sheng, T. Y., Shamsudin, M. N., Mohamed, Z., Abdullah, A. M. and Radam, A. (2008) "Complete demand systems of food in Malaysia", Agricultural Economics (Czech Republic), Vol. 54, No. 10, pp. 467-475. ISSN 0973-2276.

[18] Sheng, T. Y., Shamsudin, M. N., Mohamed, Z., Abdullah, A. M. and Radam, A. (2010) "Demand analysis of meat in Malaysia", Journal of Food Products Marketing, Vol. 16, No. 2, pp. 199-211. E-ISSN 1540-4102, ISSN 1045-4446. DOI 10.1080/10454440903415105.

[19] Shonkwiler, J. S. and Yen, S. T. (1999) "Two-Step Estimation of a Censored System of Equations", American Journal of Agricultural Economics, Vol. 81, No. 4, pp. 972-982. E-ISSN 1467-8276. DOI 10.2307/1244339.

[20] Widarjono, A. and Rucbha, S. M. (2016) "Household Food Demand in Indonesia: a Two-Stage Budgeting Approach", Journal of Indonesian Economy and Business, Vol. 31, No. 2, pp. 163-177. E-ISSN 2338-5847, ISSN 2085-8272. DOI 10.22146/jieb.15287.

[21] Yen, S. T., Kan, K. and Su, S. J. (2002) "Household demand for fats and oils: Two-step estimation of a censored demand system", Applied Economics, Vol. 34, No. 14, pp. 1799-1806. E-ISSN 1466-4283, ISSN 0003-6846. DOI 10.1080/00036840210125008.

[22] Zheng, Z., Henneberry S. R., Zhao, Y. and Goa, Y. (2019) "Predicting the changes in the structure of food demand in China", Agribusiness, Vol. 35, No. 3, pp. 301-328. E-ISSN 1520-6297. DOI 10.1002/agr.21592.

[23] Zheng, Z. and Henneberry, S. R. (2010) "An Analysis of Food Grain Consumption in Urban Jiangsu Province of China", Journal of Agricultural and Applied Economics, Vol. 42, No. 2, pp. 337-355. E-ISSN 2056-7405, ISSN 1074-0708. DOI 10.1017/s1074070800003497.

[24] Zheng, Z. and Henneberry, S. R. (2012) "Estimating the impacts of rising food prices on nutrient intake in urban China", China Economic Review, Vol. 23, No. 4, pp. 1090-1103. ISSN 1043-951X. DOI 10.1016/j.chieco.2012.07.001. 